\title{
Academic mobility development in Russian education \\ under the Bologna process
}

\author{
Seninets, Maria \\ Universidad Autónoma de Madrid, Facultad de Formación del Profesorado y Educación. \\ Departamento de Didáctica y Teoría de la Educación, Madrid, España \\ mkseninets@gmail.com \\ Vorochkov, Anton \\ Universidad Autónoma de Madrid, Facultad de Formación del Profesorado y Educación. \\ Departamento de Didáctica y Teoría de la Educación, Madrid, España \\ vorochkov@gmail.com
}

\section{Abstract}

After the period of drastic changes in social policy of the 1990s (transition from communism to neoliberalism and introduction of new public management), in the new century Russian education faced new challenges - implementation of Bologna principles and internationalization of Russian Higher Education Institutes (HEls). Under the Bologna process, Russia launched some controversial reforms aimed at integration and inclusion of Russian educational system into the European Higher Education Area (EHEA), one of the most important principles of which is seen to be development of academic and professional mobility. The article observes reforms made in the Russian Federation and initiatives of Russian Ministry of Education for academic mobility development. Most of these initiatives are devoted to full study programs realization and not to short-term mobility. Thus, it is found that 15 years after signing the Bologna declaration Russian system is still hardly ready to short-term mobility programs realization despite of all reforms made. This article is focused on analysis of the current situation of academic mobility development in Russia. It also identified the reasons for the shortage of academic mobility program and recommends for further internationalization of Russian HEls.

Keywords: supranational policy, Russian education policy, Bologna process, mobility, internationalization, higher education.

\section{INTRODUCTION}

Academic mobility always has been one of the priorities of the Bologna Process and it is seen to be a main tool for European Higher Education Area (EHEA) consolidation.

The European integration movement has expanded a lot through the years and has united also partner-countries (Altbach \& Knight, 2006). Thus, Russia signed the Bologna Declaration in 2003 and it was a start for a new period of educational reforms made in the Russian Federation. Under Bologna process Russian reformers introduced Unified State Exams, two-level system of higher education (bachelor and master), ECTS, new educational standards among others. All of them were devoted to make Russian system of higher education more compatible with the European one. Thus, these reforms it made easier for Russian students to participate in European Union programmes such as Erasmus Mundus and lately Erasmus+, but not for sufficient number of incoming students. Among the reasons are shortage of study programmes in English and little promotion of Russian education and Russian language courses. The majority of foreign students coming to study in Russia are required to do one-year course of Russian language before beginning their study programmes. This article is aimed to make an overview of academic mobility programmes in the leading Russian Universities, participants of the 5-100 Project, and reflects possible changes in the field made under the Bologna Process implementation. 


\section{ACADEMIC MOBILITY AND THE BOLOGNA PROCESS}

\subsection{Academic mobility as an essential part of the Bologna Process}

The main intention of Bologna Process is to harmonize the diverse European educational systems and, thereby, achieve a higher degree of comparability which is expected to lead to higher student mobility. Thus, the Bologna process can be seen as a process of increasing student mobility (Mechtenberg \& Strausz, 2007). As stated in the Mobility strategy 2020 for the European Higher Education Area (EHEA), 'Promoting high quality mobility of students, early stage researchers, teachers and other staff in higher education has been a central objective of the Bologna Process from the very beginning' (Mobility strategy 2020 for the European Higher Education Area (EHEA), 2012). The main tool of academic mobility enhancing in the framework of the Bologna Process and EHEE establishment has always been official programs of the European Commission: Erasmus Mundus and lately Erasmus+ Key Action 1.

Erasmus Mundus was a European Union cooperation and mobility programme in the field of higher education that aims to enhance the quality of European higher education and to promote dialogue and understanding between people and cultures through cooperation. The Erasmus Mundus programme officially ended in December 2013, however many of the projects selected in the programme are still active according to National Erasmus+ Office in the Russian Federation website.

The European Union's Erasmus+ programme is a funding scheme to support activities in the fields of Education, Training, Youth and Sport.

The Programme is made up of three so-called "Key Actions" and two additional actions. They are managed partly at the national level by National Agencies and partly at the European level by the Education, Audiovisual and Culture Executive Agency (EACEA). The European Commission is responsible for Erasmus+ policies and oversees the overall programme implementation.

According to EACEA website Erasmus+ actions managed by EACEA are the following:

\section{Key Actions}

1. Key Action 1 supports mobility in the education, training and youth sectors. It has two sub-actions:

1. Double degree master and PhD programmes and

2. Credit mobility.

2. Key Action 2 is aimed at cooperation between educational organisations from different participating countries for sharing and transferring best practices and innovative approaches in the fields of education, training and youth.

3. Key Action 3 provides grants for a wide variety of actions aimed at stimulating innovative policy development, policy dialogue and implementation, and the exchange of knowledge in the fields of education, training and youth.

\section{Additional Actions}

4. Jean Monnet is designed to promote excellence in teaching and research in the field of European Union studies worldwide

5. Sport Actions promote European dimension in sport.

Apart from financed programmes that can be seen like the most positive aspect about the Bologna Process, it brings a series of recommendations, guidelines and tools aimed to make European educational systems more comparable. 


\subsection{Bologna tools for higher comparability}

The most changes in the educational systems participated in the Bologna Process. The main Bologna tools are the following:

1. Two (later three) level degree system: first level - bachelor, second level - master, third level - PhD.

2. Credit system: ECTS.

3. European Qualification Framework (EQF).

4. Quality Assurance.

5. Recognition.

6. Academic mobility.

Since Russia signed the Bologna Declaration it has been converted in the main reference for Russian educational reforms. In this context the Federal Law in Education 273 (2012) legally establishes the majority of Bologna tools. According to this law current Russian system of higher education consists of three levels: 1) bachelor (4 years study); 2) master (two years after bachelor) or specialist (5 years); 3 ) highly qualified personnel training ( 3 years after master or specialist).

Figure 1. Levels of Russian system of higher education.

\begin{tabular}{|c|c|c|}
\hline $\begin{array}{c}\text { Bachelor } \\
(4 \text { years }) \\
\text { EQF Level 6 }\end{array}$ & $\begin{array}{c}\text { Master } \\
\text { (2 years) } \\
\text { EQF Level 7 }\end{array}$ & $\begin{array}{c}\text { Highly qualified } \\
\text { personnel training } \\
\text { (3 years) }\end{array}$ \\
\hline \multicolumn{2}{|c|}{$\begin{array}{c}\text { Specialist } \\
\text { (5 years) }\end{array}$} & EQF level 8 \\
\hline
\end{tabular}

The credit system was firstly introduced by Federal State Educational Standards of 2011. Later in 2013 it was connected with learning outcomes in accordance with recommendations of the ECTS Guideline.

There is still no National Qualification Framework in Russia, but Professional Standards have been introduced what can be seen like a first step towards the National Qualification Framework development. It should mentioned that there is a discord between Educational and Professional Standards, because they are designed by different ministries, the Educational Standards - by Ministry of Education and Science of Russian Federation and the Professional ones - by Ministry of Labor.

In the field of quality assurance there are also many changes and initiatives. The most significant is introduction of public, professional and independent accreditation.

Recognition is guaranteed by Agreements with other countries and a list of foreign organization diplomas of which are recognized in the Russian Federation. In other cases the recognition can be made by "Glavexpertcenter" that has the status of National Information Center of ENIC-NARIC Networks or by the university itself if it is leading, federal or national research university (data from Analytic note based in material of National report of the Russian Federation for MINISTERIAL CONFERENCE YEREVAN 2015).

\subsection{Academic mobility}

According to the definition of UNESCO, the academic mobility implies a period of study, teaching and/ or research in a country other than a student's or academic staff member's country of residence. This period is of limited duration, and it is envisaged that the student or staff member return to his or her home country upon completion of the designated period. The term "academic mobility" is not intended to cover migration from one country to another. Academic mobility may be achieved within exchange programmes set up for this purpose, or individually. 
A researcher from Moscow Margarita Tokmovceva distinguishes horizontal and vertical mobility on one axis and also incoming and outgoing mobility on another axis (Tokmovceva, 2015):

- Vertical academic mobility is a full training of a student in a foreign university with a degree.

- Horizontal mobility is a studying abroad for a certain period (semester, academic year).

- Incoming mobility is a transfer of students and teachers from their country abroad

- Outgoing mobility is a transfer of foreign citizens with educational goals to the country.

Consequently, we can represent the directions of academic mobility in form of a matrix (Figure 2).

Figure 2. Types of international academic mobility

\begin{tabular}{|c|c|}
\hline & \\
\hline $\begin{array}{c}\text { Incoming } \\
\text { horizontal } \\
\text { academic } \\
\text { mobility }\end{array}$ & $\begin{array}{l}\text { Incoming } \\
\text { vertical } \\
\text { academic } \\
\text { mobility }\end{array}$ \\
\hline $\begin{array}{c}\text { Outgoing } \\
\text { horizontal } \\
\text { academic } \\
\text { mobility }\end{array}$ & $\begin{array}{l}\text { Outgoing } \\
\text { vertical } \\
\text { academic } \\
\text { mobility }\end{array}$ \\
\hline
\end{tabular}

Despite the fact that academic mobility includes PhD students, teachers and other categories of participants of educational process, the paper primarily focused on student's mobility (bachelors, masters) as the most common field of mobility.

In addition, the paper shed light on academic mobility in the international area, rather than the domestic academic mobility.

\section{ACADEMIC MOBILITY IN RUSSIAN UNIVERSITIES}

\subsection{Target group of Russian universities}

For analysis of academic mobility in Russia, a relevant group of universities is selected for a detailed study of statistics on required indicators. This group includes 21 universities participating in the 5-100 Project, the Russian initiative for increasing the competitiveness of the leading universities. Official website of the Program notes that the goal of Project 5-100 is to maximize the competitiveness of a group of leading Russian universities in the global research and education market. The main results expected of the 5-100 Project by 2020 are that Russia will have a group of leading contemporary universities with an effective management structure, and a strong international academic reputation which meets global development trends and can quickly adapt to global changes. At least five Russian universities have to be in top-100 world rankings by 2020 .

All universities of this program can be attributed to group of leading universities in Russia, but there are other leading universities which are not included into the 5-100 Project, including the Moscow State University and St. Petersburg State University. One of target indicators of the 5-100 Project is development of academic mobility, thus study of this universities is of particular interest.

Data on the universities is given according to data of the Monitoring of effectiveness of organizations of higher education in 2017 (See the Table 2). The data took into account the head universities, but not the branches. 
Table 2. Data on international academic mobility of the 5-100 Project universities.

\begin{tabular}{|c|c|c|c|c|c|}
\hline Universities & $\begin{array}{l}\text { Total } \\
\text { number of } \\
\text { students }\end{array}$ & $\begin{array}{c}\text { Percentage of students } \\
\text { participating in the } \\
\text { programs of horizontal } \\
\text { mobility, } \%\end{array}$ & $\begin{array}{l}\text { Percentage of } \\
\text { foreign students in } \\
\text { the total number of } \\
\text { students, } \%\end{array}$ & $\begin{array}{c}\text { Number of } \\
\text { double degree } \\
\text { programs }\end{array}$ & $\begin{array}{l}\text { Number of } \\
\text { students } \\
\text { studied on } \\
\text { double degree } \\
\text { programs }\end{array}$ \\
\hline $\begin{array}{c}\text { Far Eastern } \\
\text { Federal University }\end{array}$ & 17554 & 0.58 & 7.47 & 4 & 212 \\
\hline $\begin{array}{l}\text { National Research University } \\
\text { Higher School of Economics }\end{array}$ & 21518 & 1.2 & 7.82 & 44 & 4194 \\
\hline ITMO University & 10357 & 0.85 & 11.94 & 35 & 305 \\
\hline $\begin{array}{l}\text { Saint Petersburg } \\
\text { Electrotechnical } \\
\text { University "LETI" }\end{array}$ & 7384 & 0.23 & 14.98 & 2 & 11 \\
\hline Kazan Federal University & 23932 & 0.77 & 9.31 & 9 & 59 \\
\hline $\begin{array}{l}\text { National University of } \\
\text { Science and } \\
\text { Technology MISIS }\end{array}$ & 7519 & 0.24 & 20.97 & 11 & 26 \\
\hline $\begin{array}{c}\text { National Research Nuclear } \\
\text { University MEPHI }\end{array}$ & 6550 & 3.21 & 17.68 & 31 & 305 \\
\hline $\begin{array}{c}\text { Moscow Institute of Physics } \\
\text { and Technology }\end{array}$ & 6095 & 0.25 & 8.88 & 12 & 59 \\
\hline Novosibirsk State University & 6751 & 0.28 & 7.18 & 10 & 30 \\
\hline Lobachevsky University & 10622 & 0.68 & 2.55 & 11 & 7 \\
\hline $\begin{array}{c}\text { Samara National } \\
\text { Research University }\end{array}$ & 10711 & 0 & 4.3 & 3 & 0 \\
\hline $\begin{array}{c}\text { St. Petersburg Polytechnic } \\
\text { University }\end{array}$ & 20683 & 1.72 & 10.25 & 24 & 217 \\
\hline $\begin{array}{c}\text { National Research Tomsk } \\
\text { State University }\end{array}$ & 10640 & 0.3 & 12.98 & 9 & 114 \\
\hline $\begin{array}{l}\text { National Research Tomsk } \\
\text { Polytechnic University }\end{array}$ & 8987 & 1.34 & 24.73 & 23 & 290 \\
\hline Ural Federal University & 24632 & 0.65 & 5.57 & 26 & 542 \\
\hline $\begin{array}{l}\text { Immanuel Kant Baltic } \\
\text { Federal University }\end{array}$ & 5824 & 0.79 & 4.94 & 2 & 5 \\
\hline $\begin{array}{l}\text { I.M. Sechenov First Moscow } \\
\text { State Medical University }\end{array}$ & 15160 & 0.05 & 9.98 & 3 & 15 \\
\hline Siberian Federal University & 23248 & 0.33 & 1.74 & 1 & 3 \\
\hline South Ural State University & 16692 & 0.59 & 7.78 & 8 & 30 \\
\hline RUDN University & 19350 & 2.33 & 23.76 & 96 & 316 \\
\hline University of Tyumen & 9516 & 0.57 & 10.33 & 3 & 62 \\
\hline
\end{tabular}




\subsection{Outgoing horizontal mobility}

In Russia at the moment this type of mobility is not developed enough. Even in case of comparing the group of leading universities in Russia and all Spanish universities there is a significant discrepancy in the indicators of outgoing mobility. While only one program Erasmus+ in Spain in 2016 supported $3,34 \%$ of university students (49 797 people) to study in another country, among students of the 5-100 Project universities the percentage of full-time students who studied abroad for at least a semester for the entire period of training, is $0,84 \%$.

Obviously, the proportion of this category of students on average across the country would be even lower. However, this paper highlights some universities that have succeeded in outgoing academic mobility. Among them, National Research Nuclear University MEPhI (3.21\% of students) and RUDN University $(2.33 \%$ of students).

Among positive trends this paper highlights increasing number of double degree programs and therefore number of students studying thereon. Double degree programs are programs based on comparability and synchronization of educational programs of partner universities and characterized by acceptance of general obligations on such issues as preparing a curriculum, organizing training process, assigning qualifications, etc. In according to report "Analysis of double degree programmes between EU and Russian HEls" (2010) these programs appeared in Russian universities in the early 2000s.

At the moment, this paper observe the leading universities in establishment of these programs: National Research University Higher School of Economics (HSE) - 44 programs, MEPhl - 31 programs, Tomsk Polytechnic University (TPU) - 23 programs, RUDN - 96 programs. According to the number of students passing the double degree program, the HSE stands out prominently: there are more students who participate in these programs than in all other universities of the 5-100 Project taken together - 4149 students.

\subsection{Outgoing vertical mobility}

Concerning this type of mobility (full cycle of study abroad), it is necessary to consider an assessment of overall situation in the country. UNESCO in its monitoring for 2015 estimated that more than 50000 Russian students studying abroad, it is $1.5 \%$ of the global number of foreign students. The most popular destinations for this type of mobility for Russians are the United States of America and the United Kingdom. It is widely believed that there are many students who want to immigrate to a country of study after the end of an educational program.

In order to prevent the leakage of human capital, the Ministry of Education and Science of Russia undertook attempts to curb the flow of those who leave the country to study abroad by offering citizens an opportunity to participate in state-financed programs for studying abroad in the world leading universities. So from 2014 to 2017 in the framework of the Global Education program, 718 Russians who enrolled in master and PhD programs in foreign universities received financial support. After graduation it is compulsory to work in Russian companies for at least three years.

\subsection{Incoming vertical mobility}

This type of mobility is one of strategic priorities of Russia in the field of education. In addition to development of educational system in the country, the presence of foreign students in universities also contributes to acquisition of so-called "Soft Power" in the long term expectations.

Perhaps incoming vertical mobility is the most developed in Russia. Minister of Education and Science, Olga Vasilieva, at the forum of interregional cooperation between Russia and Kazakhstan in 2017 called a number of foreign citizens studying in the country - 273 thousand students. In her opinion up to 760000 foreigners will study in Russia by 2025 (Rossiyskaya Gazeta, 2017).

Some categories of foreigners can study in the Russian universities for free and get scholarship on a par with Russian citizens. For this it is necessary to pass a competitive selection (pass exams). An- 
nually the Government of Russia allocates a guaranteed number of the budget (state scholarships) for foreigners in universities of the country. 15000 scholarships were allocated in 2017 in according to "Study in Russia" website.

The Higher School of Economics issued in 2016 a report about academic mobility of foreign students in Russia. There is detailed information about profile of the participants. Here is the most interesting data:

The total number of foreign students in Russia at the beginning of the 2015/2016 academic year was 237538 people (5\% of the total number of students in Russia). Most of them are students from countries of the former USSR ( $79,2 \%$ of foreign students). $20,8 \%$ of the non-former USSR foreign students are from other countries, $56,8 \%$ of them are from Asian regions. In the context of global educational competition, the goal of Russian HEls is to increase the proportion of students from Europe and the Asia-Pacific region.

The most popular areas for foreign students are health, economics and management, as well as humanities. Foreign citizens studied in about $96 \%$ of the head Russian universities and $75 \%$ of the branches. At the same time, the distribution of the total number of students is disproportional: $90 \%$ of universities and branches have only $20 \%$ of foreign students (HSE, 2016).

In accordance with the expected results of the 5-100 Project by 2020, there is a target for academic mobility of students: the proportion of foreign students must be at least $15 \%$ of the international students in each University's student body.

The average indicator for total number of students at 21 universities is quite close to the target: $12.69 \%$ of foreign students. At the same time, such universities as National University of Science and Technology MISIS, MEPhl, TPU and RUDN have a higher indicator: $20.97 \%, 17.68 \%, 24.73 \%$ and $23.76 \%$ respectively.

Almost all websites of the universities of the 5-100 Project include detailed information for foreign students on entry exams, getting visa to study in Russia, etc. The information is provided in English and other languages. This additionally indicates the ongoing work to attract foreign students to study in Russian universities.

\subsection{Incoming horizontal mobility}

For now, this area of academic mobility is not developed enough. Students willing to study in Russia for one semester or an academic year have few opportunities to realize their aspirations. It is difficult to find an effective bilateral exchange program.

Analyzing websites of the 5-100 Project universities it is revealed that despite the detailed information for people who want to pass full study, it is very difficult to find information on the passage of horizontal mobility (internship, included training, etc.). It is also difficult to find analytical materials with assessment of situation in Russia regarding this field of mobility.

\section{CONCLUSIONS}

The Bologna Process stimulated a range of institutional changes in Russian educational system and these changes led to increase in the number of students participating in academic mobility programmes, but it is still not a priority for Russian education policy like it is for the European one.

As observed in this paper, the outgoing vertical mobility is the most developed. It means that Russian students studying their bachelor or master degree have been moved for their further studies abroad. There are also many foreign students doing full study programmes in Russian HEls, but they are mostly originated from post-soviet and Asian countries meanwhile Russians go mostly to Europe or USA. The most problematic is the short-term mobility both in outgoing and incoming. It can be explained by large preparation work to be done for the period of studies. Thus it is recommended that Russian educational authorities should pay more attention to short-term academic mobility development by providing institutional tools as well as administrative and informational support. 


\section{BIBLIOGRAPHY \& REFERENCES}

Altbach, P. G. \& Knight, J. (2006). The Internationalization of Higher Education: Motivations and Realities. The NEA. Almanac of higher education, 3-10.

Analytic note based in material of National report of the Russian Federation for Ministerial Conference Yerevan 2015. Retrieved from http://www.acur.msu.ru/docs/reference_national_report.pdf.

Definition of the academic mobility. Retrieved June 28, 2018, from UNESCO website. http://www.unesco.org/education/ studyingabroad/what_is/mobility.shtml.

EACEA official website: https://eacea.ec.europa.eu/erasmus-plus_en.

Higher School of Economics (2016, July). Academic mobility of foreign students in Russia. Facty obrazovania, issue 7. Retrieved from https://5top100.ru/upload/iblock/750/fo7.pdf.

Hozhdenie za diplomom. (2017). Retrieved June 28, 2018, from Rossiyskaya Gazeta website, https://rg.ru/2017/11/13/chislo-inostrannyh-studentov-v-rossii-vyrastet-vtroe.html.

IBF International Consulting. (2010). Analysis of double degree programmes between EU and Russian HEls. Final report. Retrieved from http://www.spbstu.ru/upload/inter/final_report.pdf.

Main information and computing center of Ministry of Education and Science of the Russian Federation. (2017). Monitoring of effectiveness of organizations of higher education [Data source]. Retrieved from http://indicators.miccedu.ru/ monitoring/?m=vpo.

Mechtenberg, L. \& Strausz, R. (2008). The Bologna process: how student mobility affects multicultural skills and educational quality. International Tax and Public Finance, Volume 15, Issue 2, pp. 109-130. DOI: https://doi.org/10.1007/s10797007-9040-1.

Mobility strategy 2020 for the European Higher Education Area (EHEA). Retrieved from https://media.ehea.info/file/2012_Bucharest/39/2/2012_EHEA_Mobility_Strategy_606392.pdf.

National Erasmus+ Office in the Russian Federation official website: http://erasmusplusinrussia.ru/index.php/ru/.

Tokmovceva M. V. (2013). Problems of academic mobility in view of enactment of new Federal law «About education in Russian federation». Social-economic and psychological problems of management: conference, Moscow. 449-464. Retrieved from http://psyjournals.ru/files/63145/35_Tokmovceva.PDF.

UNESCO Institute of Statistics. (2018). Data for the Sustainable Development Goals [Data source]. Retrieved from http://uis. unesco.org/. 